\section{Simulating social distancing measures in household and close contact transmission of SARS-CoV-2}

Simulação de medidas de distanciamento intradomiciliar e transmissão do SARS-CoV-2 por contatos próximos

\section{Simulando medidas de distanciamiento social en el hogar y transmisión del SARS-CoV-2 por contacto cercano}

COMUNICAÇÃO BREVE BRIEF COMMUNICATION
Carlos Garcia Filho 1

doi: 10.1590/0102-311X00099920

\begin{abstract}
We sought to evaluate contact rate reduction goals for household and close contacts and to provide preventive recommendations during the coronavirus pandemic. We applied an agent-based model to simulate the transmission dynamics of SARS-CoV-2 within household or close contacts through a social network of 150 nodes. there is no great difference in total infected people within modifications in number of links per node for networks with average number of links per node greater than three. For six nodes, total infected people are 149.85; for five nodes, 148.97; and for four nodes, 141.57. On the other hand, for three nodes, total infected are 82.39, for two nodes, 13.95; and for one node, 2.96. This model indicates a possible pitfall if social distancing measures are not stepwise suspended and close surveillance of cases are not provided, since the relationship between average links per node and number of infected people seems to be s-shaped, and not linear.
\end{abstract}

Infectious Disease Transmission; Biological Models; Severe Acute Respiratory Syndrome

\author{
Correspondence \\ C. Garcia Filho \\ Universidade de Fortaleza. \\ Av. Washington Soares 1321, Fortaleza, CE 60811-905, Brasil. \\ cgarciafilho@gmail.com \\ 1 Universidade de Fortaleza, Fortaleza, Brasil.
}




\section{Introduction}

Several studies estimate the basic reproduction number $\left(\mathrm{R}_{0}\right)$ for severe acute respiratory syndrome coronavirus 2 (SARS-CoV-2). Most of those studies estimate $\mathrm{R}_{0}$ between 2 and 4 , but it is possible to reach values close to 8 , considering the confidence interval range $1,2,3,4,5,6,7$.

Considering a $\mathrm{R}_{0}$ of 8 , it would be necessary to reduce the contact rate for each infectious case by about $90 \%$, and for asymptomatic people by about $78 \%$, to reach a $\mathrm{R}_{0}$ of less than 1 if we want to achieve effective results of social distancing measures 8 .

However, this contact rate reduction considers the average dynamics of transmission and do not provide information about specific situations such as household transmission or close contacts, in schools or offices.

The secondary attack rate (SAR) is the probability that an infection occurs among susceptible people within a specific group, which can indicate transmission risk related to social interactions. The estimated SAR among close contacts of SARS-CoV-2 is $35 \% 9$.

In our study, we used an agent-based model (ABM) to evaluate contact rate reduction goals for household and close contacts and provide preventive recommendations during the coronavirus pandemic.

\section{Methods}

ABM is a computer simulation technique used for model behaviors of independent individuals or groups. Individual interactions are used to explore the individual impact on aggregate level. ABM can simulate complex systems by setting up simple rules for their agents 10 .

We used NetLogo (http://ccl.northwestern.edu/netlogo/), a programmable modeling environment, to simulate the SARS-CoV-transmission within close contacts and the RNetLogo package to embed ABM model into the R environment for analysis 11.

\section{Model description}

The model is an adaptation and extension of Virus on a Network 12 and Virus 13 models that shows how SARS-CoV-2 spreads through a social network. Each node represents a person and all links represent reciprocal relationships. We model the progress of an infection through these links. Each node may be in one of four states: healthy and susceptible to infection, sick and infectious (a symptomatic or asymptomatic person transmitting the virus to other people), sick and not infectious (an infected and symptomatic person that ceases physical contact with susceptible people), and healthy and immune. Each step of the simulation, named "tick", represents one day, and the simulation comprises 365 ticks. People may die due to the infection according to the chance of recovery. All links of dead people are excluded.

\section{Model parameters (Box 1)}

We estimated the number of possible close contacts of a person using de Dunbar's number ${ }^{14}$. SAR value was obtained on a study of household transmission 9. Chance-recover was set based on Brazilian lethality data (Brazilian Ministry of Health. https://covid.saude.gov.br/, accessed on 26/Apr/2020). We estimated duration as the sum of max incubation period (from 2 to 14 days) and the recommendation for discontinuation of transmission-based precautions (7 days have passed since symptoms first appeared) 15 . Immunity length was set to 365 , although duration of immunity to SARS-CoV-2 infection is not yet known 15. We estimated the case isolation lag as the median incubation period (approximately five days) 16 plus two days, which simulate a delay on diagnosis and isolation. Those values are imprecise, since the period of infectiousness for SARS-CoV-2 is not yet established 15 . Therefore, we assume that all symptomatic cases are diagnosed and isolated from susceptible people two days after the onset of symptoms. Asymptomatic cases proportion was set to $18 \% 17$. They were considered able to transmit the disease and were not isolated from susceptible people, although their role in transmission is unsettled 15,17 . 
Box 1

Description of model parameters and values.

\begin{tabular}{|c|c|c|}
\hline PARAMETER & DEFINITION & VALUE \\
\hline NUMBER-OF-NODES & Controls the initial amount of infected \\
\hline INITIAL-OUTBREAK-SIZE & Controls the transmissibility of the virus, that is, the secondary attack rate (SAR) \\
\hline VIRUS-SPREAD-CHANCE & Controls the likelihood of an infection ending up in recovery and immunity \\
\hline CHANCE-RECOVER & Controls the number of days before an infected person dies or recovers \\
\hline DURATION & Controls the number of days an immune person remains immune \\
\hline IMMUNITY-TIME & Controls the number of days before an infected person is isolated and stop transmitting the virus & 21 days \\
\hline ISOLATE-TIME & Controls the chance of identify an infected person. Only asymptomatic cases are not detected & 82\% \\
\hline CHANCE-DETECT & Controls the average number of links per node in the graph \\
\hline AVERAGE-NODE-DEGREE & & $1,2,3,4,5,6$ \\
\hline
\end{tabular}

\section{Results}

Results are based on mean number of infected people after 100 simulations of the model (Figures 1 and 2).

The peak of cases is 149.76 (95\%CI: $149.57-149.95)$ for six links per node; 142.99 (95\%CI: $140.76-$ 145.22) for five links per node; 113.69 (95\%CI: 108.68-118.70) for four links per node; 46.41 (95\%CI: 40.17-52.65) for three links per node; 11.98 (95\%CI: 10.30-13.66) for two links per node; and 3.00 (95\%CI: 2.59-3.41) for one link per node. Visual inspection of the curve suggests a flattening of the curve on three links per node level.

In simulated scenarios, there is no great difference in total infected people within modifications in number of links per node for networks with average number of links per node greater than three. For six nodes, total infected are 149.85 (95\%CI: 145.28-154.43); for five nodes, 148.97 (95\%CI: 141.94156.01); and for four nodes, 141.57 (95\%CI: 130.62-152.53).

On the other hand, the reduction of links implies major changes in total infected for networks with average number of links per node equal or bellow three. For three nodes, total infected are 82.39 (95\%CI: 68.30-96.49), for two nodes, 13.95 (95\%CI: 10.60-17.31); and for one node, 2.96 (95\%CI: 2.48-3.45). 
Figure 1

Estimated cases over time by average number of links per node in the network graph.

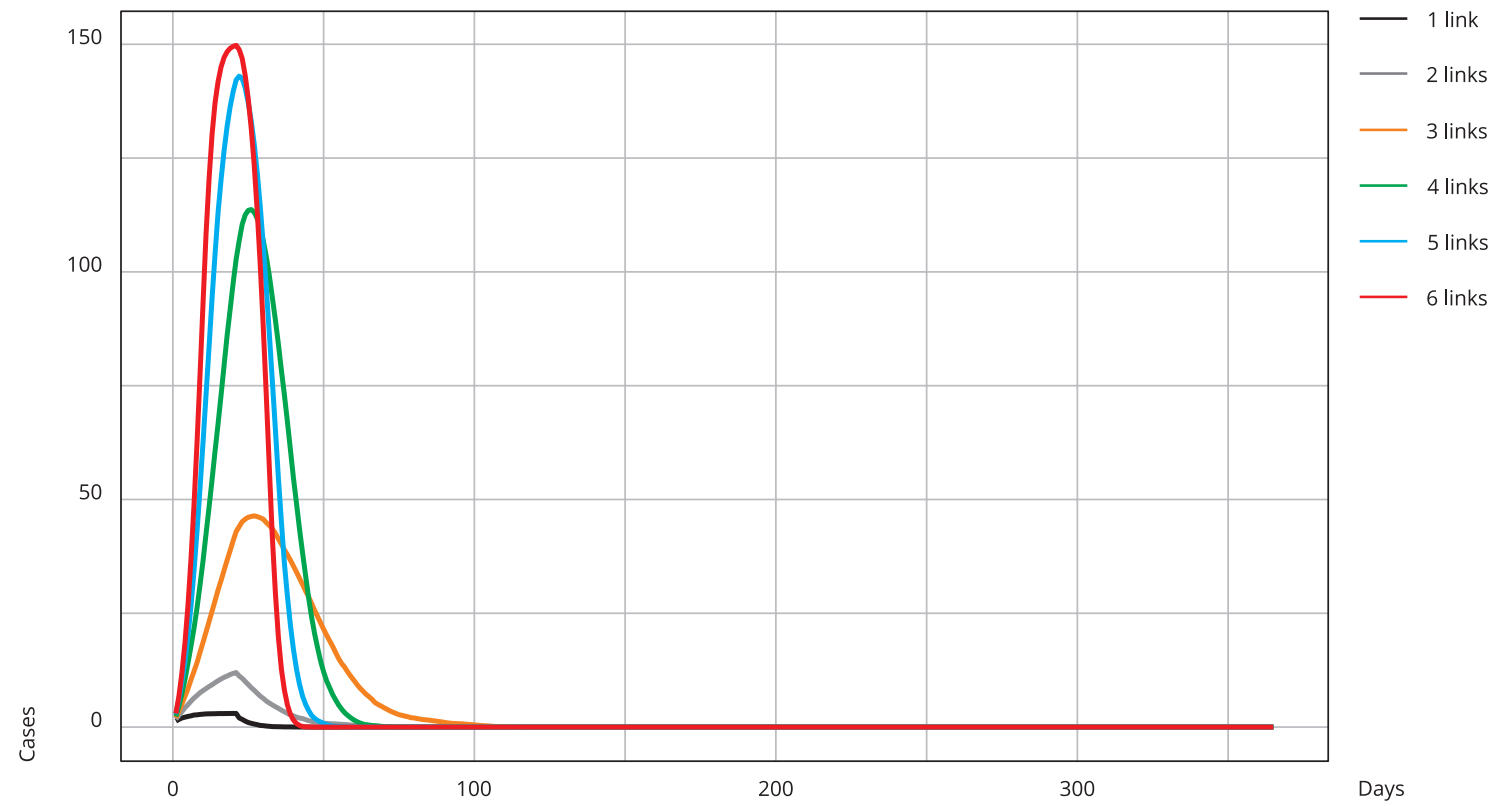

Figure 2

Total estimated cases over time by average number of links per node in the network graph.

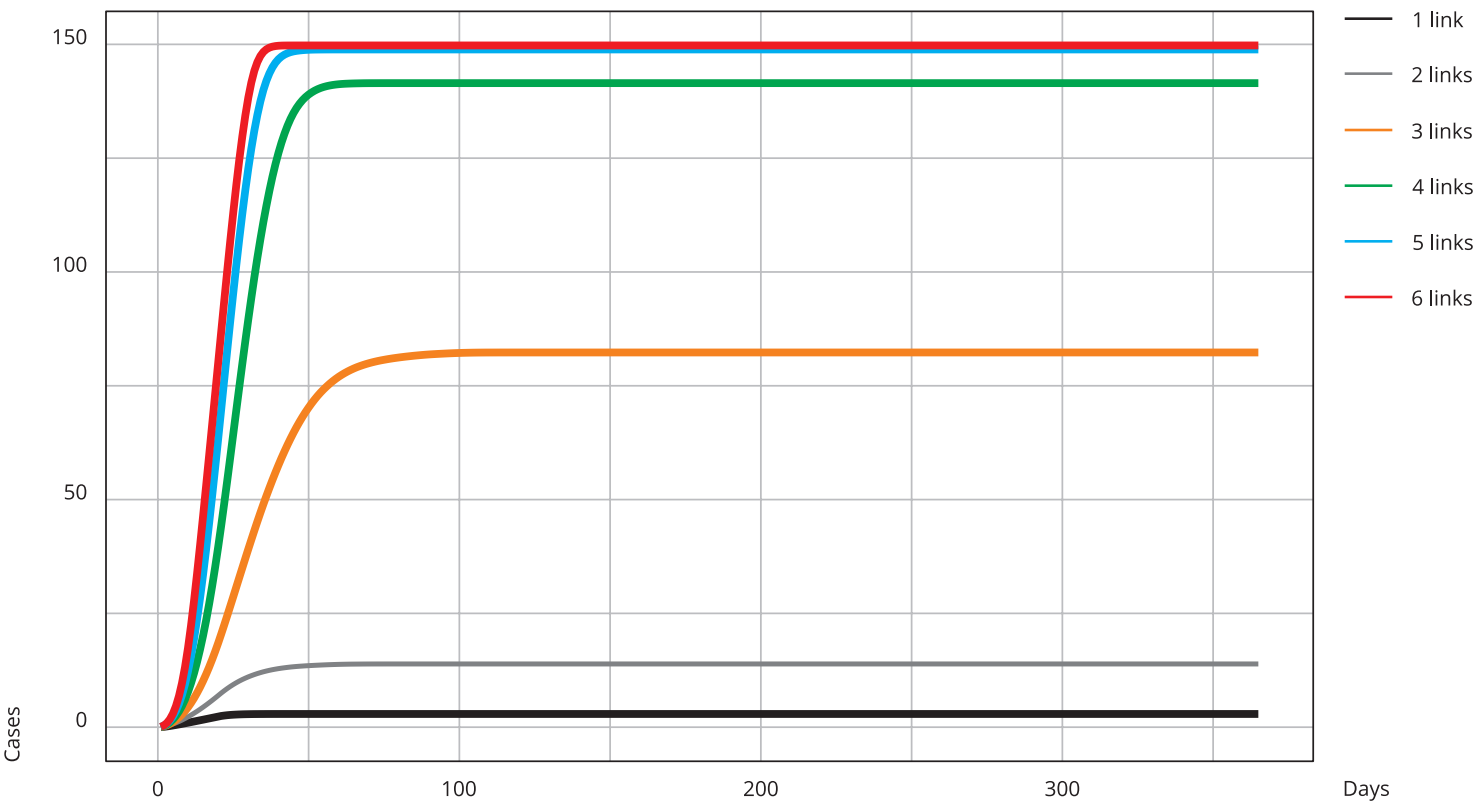




\section{Discussion}

Contact rate reduction is a widespread preventive measure adopted against SARS-CoV-2 pandemics and simulations confirms its effectiveness 18. In Brazil, social distancing measures started on March 11 th in the Federal District, subsequently expanded to other Federation Units 19; however, there is a claim to relax these measures given the impacts on economic growth 20.

Household and close transmission should be evaluated as community transmission, since contact patterns between individuals are dynamic and heterogeneous across distinct scenarios 9 .

The model presented indicates a possible pitfall if social distancing measures are not stepwise suspended, since the relationship between the average links per node of networks and the number of infected people seems to be s-shaped, and therefore, not linear.

Our study has several limitations. First, since models are simplifications of reality, unforeseen factors may play a key role in the dissemination of the disease. Second, the epidemiological characteristics of SARS-CoV-2 pandemics are still uncertain, including the role of asymptomatic individuals in transmission, period of infectiousness and of immunity after infection 15 . Third, the interpretation of $\mathrm{R}_{0}$ is complex and its value is affected by biological, sociobehavioral and environmental factors, thus, it cannot be considered the same within different scenarios 21 .

A recommendation for public health authorities is to set a long-range schedule of social distancing suspension measures, such as organizing the return of children to school according to their grade, and to provide a close surveillance of cases.

\section{Acknowledgments}

The author would like to acknowledge the University of Fortaleza (Unifor) for supporting this research.

\section{References}

1. Kuniya T. Prediction of the epidemic peak of coronavirus disease in Japan, 2020. J Clin Med 2020; 9:789.

2. Zhao S, Lin Q, Ran J, Musa SS, Yang G, Wang $\mathrm{W}$, et al. Preliminary estimation of the basic reproduction number of novel coronavirus (2019-nCoV) in China, from 2019 to 2020: a data-driven analysis in the early phase of the outbreak. Int J Infect Dis 2020; 92:214-7.

3. Zhao S, Cao P, Gao D, Zhuang Z, Cai Y, Ran $\mathrm{J}$, et al. Serial interval in determining the estimation of reproduction number of the novel coronavirus disease (COVID-19) during the early outbreak. J Trav Med 2020; 27 :taaa033.

4. Choi SC, Ki M. Estimating the reproductive number and the outbreak size of COVID-19 in Korea. Epidemiol Health 2020; 42:e2020011.

5. Tuite AR, Fisman DN. Reporting, epidemic growth, and reproduction numbers for the 2019 novel coronavirus (2019-nCoV) epidemic. Ann Intern Med 2020; 172:567-8.

6. Fang Y, Nie Y, Penny M. Transmission dynamics of the COVID-19 outbreak and effectiveness of government interventions: a data-driven analysis. J Med Virol 2020; 92:645-59.

7. Wang Y, Wang Y, Chen Y, Qin Q. Unique epidemiological and clinical features of the emerging 2019 novel coronavirus pneumonia (COVID-19) implicate special control measures. J Med Virol 2020; 92:568-76.

8. Diaz-Quijano FA, Rodriguez-Morales AJ, Waldman EA. Translating transmissibility measures into recommendations for coronavirus prevention. Rev Saúde Pública 2020; 54:43. 
9. Liu Y, Eggo RM, Kucharski AJ. Secondary attack rate and superspreading events for SARSCoV-2. Lancet 2020; 395:E47.

10. Allen TT. Introduction to discrete event simulation and agent-based modeling. London: Springer; 2011.

11. Thiele JC. R marries NetLogo: introduction to the RNetLogo package. J Stat Softw 2014; 58:1-41.

12. Stonedahl F, Wilensky U. NetLogo virus on a network model. http://ccl.northwestern.edu/ netlogo/models/VirusonaNetwork (accessed on 29/Apr/2020).

13. Wilensky U. NetLogo virus model. http://ccl. northwestern.edu/netlogo/models/Virus (accessed on 01/Apr/2020)

14. Dunbar R. Grooming, gossip, and the evolution of language. Cambridge: Harvard University Press; 1998.

15. Centers for Disease Control and Prevention. Clinical questions about COVID-19: questions and answers. https://www.cdc.gov/coronavi rus/2019-ncov/hcp/faq.html (accessed on 26/ Apr/2020).

16. Lauer SA, Grantz KH, Bi Q, Jones FK, Zheng $\mathrm{Q}$, Meredith HR, et al. The incubation period of coronavirus disease 2019 (COVID-19) from publicly reported confirmed cases: estimation and application. Ann Intern Med 2020; $172: 577-82$
17. Mizumoto K, Kagaya K, Zarebski A, Chowell G. Estimating the asymptomatic proportion of coronavirus disease 2019 (COVID-19) cases on board the Diamond Princess cruise ship, Yokohama, Japan, 2020. Euro Surveill 2020; 25:2000180.

18. Koo JR, Cook AR, Park M, Sun Y, Sun H, Lim JT, et al. Interventions to mitigate early spread of SARS-CoV-2 in Singapore: a modelling study. Lancet Infect Dis 2020; [Online ahead of print].

19. Centro de Operações de Emergência em Saúde Pública, Ministério da Saúde. Especial: doença pelo coronavírus 2019. Boletim Epidemiológico 2020. https://www.saude.gov.br/images/ pdf/2020/April/06/2020-04-06-BE7-Bole tim-Especial-do-COE-Atualizacao-da-Avaliacao-de-Risco.pdf.

20. Ao menos 25 dos 27 governadores manterão restrições contra coronavírus mesmo após Bolsonaro pedir fim de isolamento. G1 2020; 25 mar. https://g1.globo.com/politica/no ticia/2020/03/25/governadoras-reagem-aopronunciamento-de-bolsonaro-sobre-coro navirus.ghtml.

21. Delamater PL, Street EJ, Leslie TF, Yang YT, Jacobsen KH. Complexity of the basic reproduction number $\left(\mathrm{R}_{0}\right)$. Emerg Infect Dis 2019; 25:1-4. 


\section{Resumo}

O estudo teve como objetivos, avaliar as metas de redução da taxa de contatos domiciliares e próximos, além de fornecer recomendações preventivas durante a pandemia do novo coronavírus. Foi aplicado um modelo baseado em agentes para simular a dinâmica da transmissão do SARS-CoV-2 dentro dos domicílios ou entre contatos próximos, através de uma rede social com 150 nós. Não houve uma diferença grande no número total de pessoas infectadas de acordo com as modificações no número de elos por nó em redes com mais de três elos por nó em média.. Para seis nós, o total de infectados é 149,85; para cinco nós, 148, 97 e para quatro nós, 141,57. Por outro lado, para três nós, o total de infectados é 82,39, para dois nós, 13,95 e para um nó, 2,96. O modelo indica uma possível armadilha, caso as medidas de distanciamento social não sejam suspendidas de maneira escalonada, com vigilância rigorosa de casos, uma vez que a relação entre a média de elos por nó e o número pessoas infectadas parece apresentar uma forma em "s", e não linear.

Transmissão de Doença Infecciosa; Modelos Biológicos; Síndrome Respiratória Aguda Grave

\section{Resumen}

El objetivo fue evaluar las metas alcanzadas en la reducción de las tasas de contacto en los hogares, así como de contactos cercanos, para proporcionar recomendaciones preventivas durante la pandemia de coronavirus. Aplicamos un modelo basado en agentes, con el fin de simular la transmisión dinámica del SARS-CoV-2 dentro del hogar o con contactos cercanos, a través de una red social de 150 nodos. No existe una gran diferencia en el total de personas infectadas en las modificaciones, respecto al número de enlaces por nodo, en el caso de las redes con un promedio de links por nodo superior a tres. En el caso de los seis nodos, el total de infectados es 149,85; con cinco nodos, 148,97; y con cuatro nodos, 141,57. Por otro lado, con tres nodos, el total de infectados es 82,39, con dos nodos, 13,95; y con un nodo, 2,96. El modelo señala el consiguiente problema, si las medidas de distanciamiento social no se suspenden escalonadamente, y se realiza una estrecha vigilancia de los casos localizados, puesto que la relación entre el promedio de enlaces por nodo y el número de personas infectadas parece que tiene forma de "s" y no es lineal.

Transmisión de Enfermedad Infecciosa; Modelos Biológicos; Síndrome Respiratorio Agudo Grave

Submitted on 27/Apr/2020

Final version resubmitted on 06/May/2020

Approved on 11/May/2020 